\title{
BARLEY ACYL CARRIER PROTEIN: ITS AMINO ACID SEQUENCE AND ASSAY USING PURIFIED MALONYL-COA:ACP TRANSACYLASE \\ by
}

\author{
PETER BORDIER HØJ1,2 \\ and
}

IB SVENDSEN3

\author{
1 Department of Physiology, Carlsberg Laboratory, \\ Gamle Carlsberg Vej 10, DK-2500 Copenhagen Valby \\ 2 Institute of Genetics, University of Copenhagen, \\ Øster Farimagsgade 2A, DK-1353 Copenhagen K \\ 3 Department of Chemistry, Carlsberg Laboratory \\ Gamle Carlsberg Vej 10, DK-2500 Copenhagen Valby
}

Keywords: Fatty acid synthetase, cyanogen bromide, carboxypeptidase Y, chromatofocusing, structure-function relationship.

Malonyl-CoA:ACP transacylase from barley (Hordeum vulgare L.) has been purified to homogeneity and used in an assay for acyl carrier protein (ACP). The transacylase is an acidic, monomeric protein with a molecular weight of 34,500 very similar to the analogous $E$. coli enzyme.

A heat and acid stable acyl carrier protein from barley has been purified to homogeneity and its chemical composition determined. The ACP consists of a continuous stretch of the following 72 amino acids $\mathrm{H}_{2} \mathrm{~N}-A-A-M$ $G-E-A-Q-A-K-K-E-T-V-D-K-V-(C ?)-M-I-V-K-K-Q-L-A-V-P-D-G-T-P-V-T-A-E-S-K-F-S-E-L-G-A-D-S-L-D-T-V-$ E-I-V-M-G-L-E-E-E-F-N-I-T-V-D-E-T-S-A-Q-D-I-A ${ }^{72} \ldots . .$. A ${ }^{87-C O O H}$. A comparison of the primary structure of this plant ACP and bacterial ACP reveals two identical sequences (underlined) in the midregion of the molecule containing the 4'-phosphopantetheine attachment site, while differences occur outside this region. Nine extra residues (italicized) are present at the $\mathrm{N}$-terminal end of the barley protein thereby accounting for its larger size. Identical products are obtained when barley chloroplast fatty acid synthetase is incubated with either barley or $\mathrm{E}$. coli $\mathrm{ACP}$, but the latter is twice as active as the former in fatty acid synthesis. The possible significance of the Nterminal part of the ACP is discussed in relation to the reported differences in biochemical activities of plant and bacterial ACPs.

Abbreviations: $\mathrm{ACP}=$ acyl carrier protein, $\mathrm{BSA}=$ bovine serum albumin, $\mathrm{CoA}=$ coenzyme $\mathrm{A}, \mathrm{DTT}=1,4-$ dithiotreitol, fas $=$ fatty acid synthetase, Hepes $=\mathrm{N}$-2-hydroxyethylpiperazine-N'-2-ethanesulfonic acid, $\mathrm{kD}=$ kilodalton, Mes $=2$-(N-morpholino)ethanesulfonic acid, Mops = 3-(N-morpholino)propanesulfonic acid, Pipes = piperazine-N,N'-bis(2-ethane sulfonic acid), PTH = phenylthiohydantoin, SDS-PAGE = sodium dodecyl sulfate polyacrylamide gel electrophoresis, Tricine $=\mathrm{N}$-(tris(hydroxymethyl) methyl) glycine, u.v. $=$ ultra violet. 


\section{INTRODUCTION}

Acyl carrier protein (ACP) which functions as the carrier of the growing fatty acid chain during fatty acid biosynthesis has been isolated and characterized from a variety of sources $(2,8,23$, $32,39,41)$. The substrate binding site of ACP is 4'-phosphopantetheine. The strict requirement for ACP in fatty acid biosynthesis of plants and bacteria implies that parts of the ACP molecule other than the prosthetic group are essential for its function. ACPs purified from spinach and $E$. coli have a remarkably similar size and amino acid composition and function interchangeably in the E. coli and plant fatty acid synthetase (fas) assay systems, but the products and their amounts vary according to the source of $\mathrm{ACP}$ used (39). Since the amino acid sequence containing the prosthetic group attachment site of these two ACP species appeared identical (22) the differences in biological activity were attributed to alterations in the amino acid sequence at some distance from the prosthetic group. In the present paper we therefore present an extensive amino acid sequence of the barley chloroplast $\mathrm{ACP}$, and compare it to that known for E. coli ACP (41). For elucidations of structure and functional relationships the malonylCoA:ACP transacylase has been purified and is compared to that of $\mathrm{E}$. coli.

\section{MATERIALS AND METHODS}

\subsection{Biological material}

Seeds of wild type barley (Hordeum vulgare cv. Svalöfs Bonus) were germinated in vermiculite moistened with tap water. Seedlings were harvested after growing for six days at $20^{\circ} \mathrm{C}$ in the dark and then six hours in continuous white light (1,700 lux). E. coli B was a kind gift from Dr. J. PrICE, University of California, Davis.

\subsection{Analytical material}

Bovine serum albumin (BSA) was purchased from Merck. N-2-hydroxyethylpiperazine-N'-2ethanesulfonic-acid (Hepes), N-(Tris(hydroxymethyl)methyl)glycine (Tricine), morpholinopropanesulfonic-acid (Mops), piperazine-N,N'bis(2-ethanesulfonic acid) (Pipes), 2-(N-Morpholino)ethanesulfonic acid (Mes), coenzyme A
(CoA) and cyanogen bromide came from Sigma. DEAE-Sepharose CL 6B, Blue Sepharose CL 6B, Polybuffer exchanger 94, Polybuffer 74, Sephacryl S-300 and Sephacryl S-200 plus Sephadex G-100 medium were products of Pharmacia, Sweden. (2-14C)-malonyl-CoA (6.3 $\left.\mathrm{mCi} \cdot \mathrm{mmol}^{-1}\right)$ (14) and pure E. coli ACP (19) were prepared. Sodium $(1-14 \mathrm{C})$-acetate $(60$ $\mathrm{mCi} \cdot \mathrm{mmol}^{-1}$ ) was purchased from the Radiochemical Centre (Amersham, England). DEAE-cellulose ion exchanger material (DE 52) was supplied by Whatman and Biogel P30 (100 200 mesh) by Bio Rad. Unless otherwise specified all other chemicals were of analytical grade and used without further purification.

\subsection{Preparation of plant extracts}

Two sources of starting material were used for the purification of malonyl-COA:ACP transacylase and ACP from barley: soluble chloroplast stroma proteins and soluble proteins from total leaf homogenates. All procedures were carried out at $4{ }^{\circ} \mathrm{C}$ unless otherwise stated.

\subsubsection{Isolation and $\left(\mathrm{NH}_{4}\right)_{2} \mathrm{SO}_{4}$ fractionation of plastid stroma proteins}

Isolation of plastids and fractionation of stroma proteins by $\left(\mathrm{NH}_{4}\right)_{2} \mathrm{SO}_{4}$ was done exactly as described in ref. 14. Proteins precipitated between 45 and $85 \%\left(\mathrm{NH}_{4}\right)_{2} \mathrm{SO}_{4}$ served as a source for malonyl-CoA:ACP transacylase (2.3.3.) and those not precipitated by $70 \%\left(\mathrm{NH}_{4}\right)_{2} \mathrm{SO}_{4}$ were used in the preparation of barley ACP (2.3.5.).

\subsubsection{Isolation and $\left(\mathrm{NH}_{4}\right)_{2} \mathrm{SO}_{4}$ fractionation of proteins from whole leaf homogenates}

A total of $3.3 \mathrm{~kg}$ leaves was harvested and homogenized in a Waring Blendor at top speed with four $30 \mathrm{sec}$ bursts and $15 \mathrm{sec}$ intervals. For the first $800 \mathrm{~g}$ of leaves $1.3 \mathrm{l}$ of media (20 mM-Mops/ $\mathrm{NaOH}$ at pH 7.0, $500 \mathrm{~mm}-\mathrm{NaCl}, 1 \% \mathrm{w} / \mathrm{v}$ polyvinyl-pyrrolidone-10, 2 mм-DTT) were used. The homogenate was squeezed through a single layer of $31 \mu \mathrm{m}$ mesh nylon gauze and then filtered through another identical gauze layer. The filtrate so obtained was used as homogenization media for the next $800 \mathrm{~g}$ lot of seedlings which were homogenized in the same manner. The final homogenate (approx. 41 ) was centrifuged at $5,000 \mathrm{x} \mathrm{g}$ for $45 \mathrm{~min}$ and the resulting superna- 
tant subjected to $\left(\mathrm{NH}_{4}\right)_{2} \mathrm{SO}_{4}$ fractionation. $\left(\mathrm{NH}_{4}\right)_{2} \mathrm{SO}_{4}$ was added gradually with stirring to $45 \%$ saturation and the solution left stirring for an additional $30 \mathrm{~min}$ before centrifugation at $5,000 \mathrm{x}$ g for $45 \mathrm{~min}$. Additional $\left(\mathrm{NH}_{4}\right)_{2} \mathrm{SO}_{4}$ was added to the new supernatant until $70 \%$ saturation was obtained. Stirring and centrifugation followed as previously. The $45-70 \%$ precipitate was dissolved in $200 \mathrm{ml}$ buffer composed of 20 mM-Mops/NaOH (pH 7.0) fortified with 1 mMDTT ( referred to as buffer A). After dialysis overnight towards 50 vols. of the same buffer, the supernatant obtained by centrifugation served as a source for malonyl-CoA:ACP transacylase (2.3.4.) either immediately or after storage at -80 ${ }^{\circ} \mathrm{C}$. ACP was recovered from the final supernatant by adding $0.1 \mathrm{mg} \cdot \mathrm{ml}^{-1} \mathrm{BSA}$, adjusting the $\mathrm{pH}$ to 1.0 with conc. $\mathrm{HCl}$ and adding solid $\left(\mathrm{NH}_{4}\right)_{2} \mathrm{SO}_{4}$ to $100 \%$ saturation. The solution was left stirring overnight whereupon precipitable proteins were collected by centrifugation at $5,000 \times \mathrm{g}$ for 1 hour. Pelleted protein was suspended in $1 \mathrm{M}$-Hepes ( $\mathrm{pH} 7.5)$ and the $\mathrm{pH}$ adjusted to 7.0 by addition of $1 \mathrm{~m}-\mathrm{NaOH}$. After dialysis overnight towards 50 vols buffer $\mathrm{A}$, the solution was either used immediately or stored at $-80^{\circ} \mathrm{C}$ before further purification (2.3.6.).

\subsubsection{Purification of malonyl-CoA:ACP transacylase from plastid stroma proteins}

The $45-85 \%\left(\mathrm{NH}_{4}\right)_{2} \mathrm{SO}_{4}$ precipitate (2.3.1.) was dissolved in $100 \mathrm{~mm}$-Tricine ( $\mathrm{pH} \mathrm{9.0)}$ fortified with $0.3 \mathrm{M}$-glycerol plus $2 \mathrm{~mm}$-DTT and thereafter gel filtrated on Sephacryl S-300 exactly as described in ref. 14. Fractions containing malonylCoA:ACP transacylase activity were pooled and applied to a $0.9 \times 50 \mathrm{~cm}$ Blue Sepharose CL 6B column equilibrated in the above buffer. The column was extensively washed until no more u.v. absorbing material was detected in the eluate. Elution was undertaken with a $640 \mathrm{ml}$ linear salt gradient $(0.0-0.5 \mathrm{M}-\mathrm{NaCl})$ in the same buffer. Fractions with high activity eluted about $0.3 \mathrm{M}-$ $\mathrm{NaCl}$. These were pooled and concentrated to 10 $\mathrm{ml}$ in an Amicon ultrafiltration device fitted with a PM 30 membrane. Using a flowrate of 24 $\mathrm{ml} \cdot \mathrm{hr}^{-1}$ the concentrate was gel filtrated on a column $(2.5 \times 76 \mathrm{~cm})$ of Sephacryl S-200 previously equilibrated in $20 \mathrm{~mm}$-histidine ( $\mathrm{pH} 5.8$ ), with $10 \mathrm{~mm}$-DTT and $0.3 \mathrm{M}$-glycerol. Separation of the enzyme on the basis of its isoelectric point was achieved by chromatofocusing. MalonylCoA:ACP transacylase containing fractions from the gel filtration step were loaded onto a column $(0.9 \times 28 \mathrm{~cm})$ of Polybuffer exchanger 94 equilibrated with the histidine buffer given above. Elution was accomplished at a flowrate of $10 \mathrm{ml} \cdot \mathrm{hr}^{-1}$ by application of Polybuffer $74 \mathrm{di}-$ luted nine-fold with water and adjusted to $\mathrm{pH}$ 4.0 with aqueous $\mathrm{HCl}$.

\subsubsection{Purification of malonyl-CoA:ACP transacylase from whole leaf homogenate}

The proteins obtained in the $40-70 \%$ $\left(\mathrm{NH}_{4}\right)_{2} \mathrm{SO}_{4}$ precipitate after dialysis (2.3.2.) were applied to a DE 52 ion exchanger $(5 \times 40 \mathrm{~cm})$

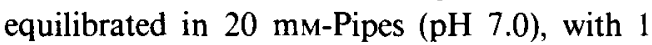
mM-DTT. After washing with three column volumes of equilibration buffer, malonyl-CoA ACP transacylase was eluted by employing a linear salt gradient $(51,0.0-0.3 \mathrm{M})$ in the same buffer. Fractions containing high activity were pooled. After dilution with distilled water to give a conductivity of $3 \mathrm{mS}$, they were loaded onto a $5 \times 41$ $\mathrm{cm}$ DEAE-Sepharose CL 6B column equilibrated with buffer $A$. Elution was again performed with a linear salt gradient $(0.05-0.2 \mathrm{M}$ $\mathrm{NaCl})$ in buffer $\mathrm{A}$. Malonyl-CoA:ACP transacylase rich fractions were pooled, $\left(\mathrm{NH}_{4}\right)_{2} \mathrm{SO}_{4}$ (90\%) precipitated, dialysed (buffer $\mathrm{A}, 2.3 .2$ ) and further fractionated by chromatography on a column $(2.5 \times 15 \mathrm{~cm})$ of Blue Sepharose CL 6B. Stepwise elution was used; that is, after loading the column was washed with two bed volumes of buffer $\mathrm{A}$, followed by two bed volumes of buffer A containing $0.175 \mathrm{M}-\mathrm{NaCl}$. The majority of the enzyme was eluted with buffer A containing 0.5 $\mathrm{M}-\mathrm{NaCl}$. Chromatofocusing followed as described in 2.3.3. Finally the pooled material from the chromatofocusing step was concentrated to $13 \mathrm{ml}$ by ultrafiltration using a PM 30 membrane and then gel filtrated on a column $(2.5 \times 80$ $\mathrm{cm}$ ) of Sephacryl S-200 equilibrated in $20 \mathrm{~mm}$ Hepes (pH 7.0), 1 mm-DTT (buffer B) fortified with $200 \mathrm{~mm}-\mathrm{NaCl}$. The enzyme after dialysis against buffer $\mathrm{A}$ (2.3.2.) was stored at -20 or -80 ${ }^{\circ} \mathrm{C}$. Recovery was approx. $3 \%$ with a purification fold of approx. 3,700. 


\subsubsection{Purification of $\mathrm{ACP}$ from $\left(\mathrm{NH}_{4}{ }_{2} \mathrm{SO}_{4}\right.$ fractionated stroma proteins}

The supernatant after $70 \%\left(\mathrm{NH}_{4}\right)_{2} \mathrm{SO}_{4}$ fractionation (2.3.1.) was heat treated, acid precipitated and processed as described earlier (14). The dissolved acid precipitate was fractionated on a Sephadex G-100 medium column $(2.5 \times 76 \mathrm{~cm})$ equilibrated in $10 \mathrm{~mm}$-sodium phosphate at $\mathrm{pH}$ 6.0 , with 1 mM-DTT. The flow rate was 15 $\mathrm{ml} \cdot \mathrm{hr}^{-1}$. Fractions containing ACP activity were pooled and loaded onto a column $(1.5 \times 3.5$ $\mathrm{cm}$ ) of DEAE-Sepharose CL 6B equilibrated in buffer $B$. Elution was achieved by incorporating a $300 \mathrm{ml}$ linear salt gradient $(0.125-0.5 \mathrm{M}-\mathrm{NaCl})$ in buffer B. Pooled material from this eluate was used for electrophoretic analysis.

\subsubsection{Purification of $\mathrm{ACP}$ from $\left(\mathrm{NH}_{4} \mathrm{SO}_{4}\right.$ fractionated whole leaf extracts}

Dialysed material from $10 \mathrm{~kg}$ of seedlings (2.3.2.) was applied to a DEAE-Sepharose CL 6B column $(5 \times 41 \mathrm{~cm})$ previously equilibrated in buffer $A$, and the column was washed with 11 of the same buffer to remove non-adsorbed material. Adsorbed proteins were eluted using 51 of $\mathrm{NaCl}$ in buffer $\mathrm{A}$ in a linear gradient, $(0.12-0.4$ M) $-\mathrm{NaCl}$. Active fractions eluting at $0.3 \mathrm{M}-\mathrm{NaCl}$ were located, pooled and dialysed against 101 of buffer $\mathrm{A}$ in standard Serva dialysis tubing to a conductivity of $3.5 \mathrm{mS}$. After centrifugation the dialysate was applied to a $2.5 \times 70 \mathrm{~cm}$ DE 52 column equilibrated in buffer $\mathrm{A}$. $\mathrm{ACP}$ was eluted with a 2.51 linear salt gradient $(0.1-0.3 \mathrm{M}-\mathrm{NaCl})$ in buffer A. ACP containing fractions were pooled and concentrated to $13.8 \mathrm{ml}$ using a PM 10 membrane. Separation of proteins according to size was accomplished with a Sephacryl S-200 $(2.5 \times 80 \mathrm{~cm})$ column equilibrated in buffer $B$ containing $200 \mathrm{mM}-\mathrm{NaCl}$. Flowrate and fraction size were $3 \mathrm{~cm} \cdot \mathrm{hr}^{-1}$ and $4.8 \mathrm{ml}$ respectively. Fractions rich in ACP were pooled and dialysed against $20 \mathrm{~mm}$-histidine (pH 6.2) with $2 \mathrm{mM}$ DTT before application to a $0.9 \times 28 \mathrm{~cm}$ column of Polybuffer exchanger 94 equilibrated in the same buffer. Elution of bound material was done by using seven-fold diluted Polybuffer 74 at $\mathrm{pH}$ 3.6 fortified with $2 \mathrm{mM}$-DTT. After pooling of the active fractions, the $\mathrm{pH}$ was adjusted to 6.6 with $2 \mathrm{M}-\mathrm{NaOH}$, and the sample was concentrated on a $2 \mathrm{ml}$ column of DEAE-Sepharose CL 6B. Remaining Polybuffer was removed by acid precipitation performed as in 2.3.2 except that BSA was not added as a carrier.

\subsection{Enzyme assays}

\subsubsection{Fatty acid synthetase and malonyl-} CoA:ACP transacylase assays

Assays for malonyl-CoA:ACP transacylase and fatty acid synthetase with $5 \mu \mathrm{Ci}(1-14 \mathrm{C})$-acetate as labelled precursor were performed as described in ref. 14 with the aid of radio-gas liquid chromatography (25). Barley ACP was determined as detailed in 14 except that $160 \mathrm{ng}$ of purified malonyl-CoA:ACP transacylase (2.3.4.) was used as enzyme source instead of partially purified enzyme.

\subsection{Protein, amino acid composition and sequence determinations}

Protein was determined according to BrADFORD (5) using a Bio-Rad protein assay kit I with gamma globulin as standard. For amino acid analysis samples were hydrolyzed in nitrogen flushed evacuated ampoules with $5.7 \mathrm{~N}-\mathrm{HCl}$ for 24 hours at $110^{\circ} \mathrm{C}$, dried and analyzed on a Durrum D 500 analyzer. Cysteine was determined as cysteic acid (13) or alternatively as pyridylethylcysteine (11). Polarity indices were calculated according to (6). Amino acid sequences were determined using an automatic liquid phase sequencer Beckmann model $890 \mathrm{C}$, and phenylthiohydantoin (PTH) amino acids were identified by high pressure liquid chromatography (40). In all cases hexadimetrine (Polybrene) was added to the cup.

\subsection{Carboxypeptidase $Y$ digestion}

Carboxypeptidase $Y$ free of proteinase A activity as checked on the B-chain of insulin (17) was used. Digestions were made in $50 \mathrm{~mm}$-Mes (pH 6.5) containing $0.5 \%$ SDS and norleucine as internal standard. Twenty nmoles of barley ACP were incubated with $23 \mu \mathrm{g}$ enzyme at $25^{\circ} \mathrm{C}$. At suitable time intervals aliquots were removed and acidified with $\mathrm{HCl}$ to $\mathrm{pH} 2.2$. The liquid was evaporated under nitrogen and the resulting samples dissolved and subjected to amino acid analysis. 


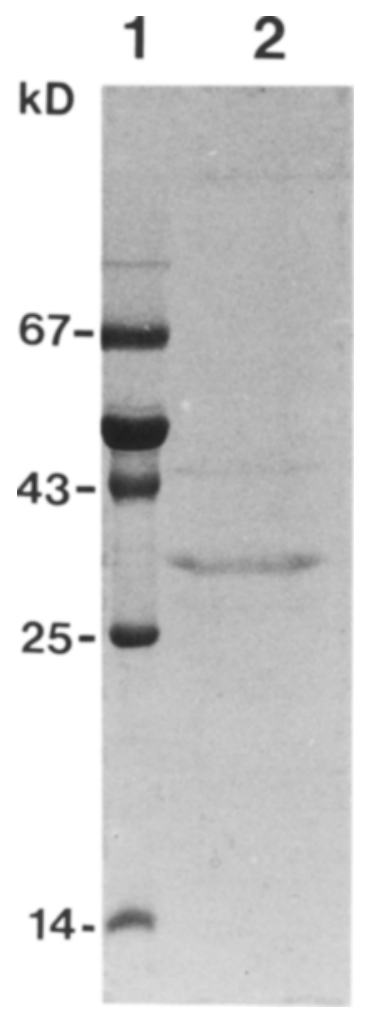

Figure 1. SDS-PAGE of malonyl-CoA:ACP transacylase purified from isolated chloroplasts (2.3.3.). The separation was carried out in a $12 \%$ system II gel at $25^{\circ} \mathrm{C}(18)$. Marker proteins (BSA, large subunit of barley ribulose bisphosphate carboxylase, ovalbumin, chymotrypsinogen $A$ and small subunit of ribulose bisphosphate caraboxylase) were analyzed in lane 1, malonyl-CoA:ACP transacylase in lane 2. Proteins were visualised with Coomassie brilliant blue.

\subsection{Preparation and purification of cyanogen bromide fragments}

150 nmoles of purified ACP was dialyzed against water fortified with $2 \mathrm{mM}$-DTT and then lyophilized. The polypeptide was dissolved in $300 \mu$ nitrogen saturated trifluoroacetic acid (70\%) and transferred to a vial containing $0.15 \mathrm{~g}$ cyanogen bromide. After stirring in the dark at $25^{\circ} \mathrm{C}$ for 28 hours, the reaction was stopped by addition of thirty volumes of water followed by freeze drying. The cyanogen bromide fragments were dissolved in $0.9 \mathrm{ml} 100 \mathrm{~mm}-\mathrm{NH}_{4} \mathrm{HCO}_{3}$ and subsequently applied to a column $(1.6 \times 90 \mathrm{~cm})$ of Biogel P30 equilibrated with $100 \mathrm{~mm}$ -

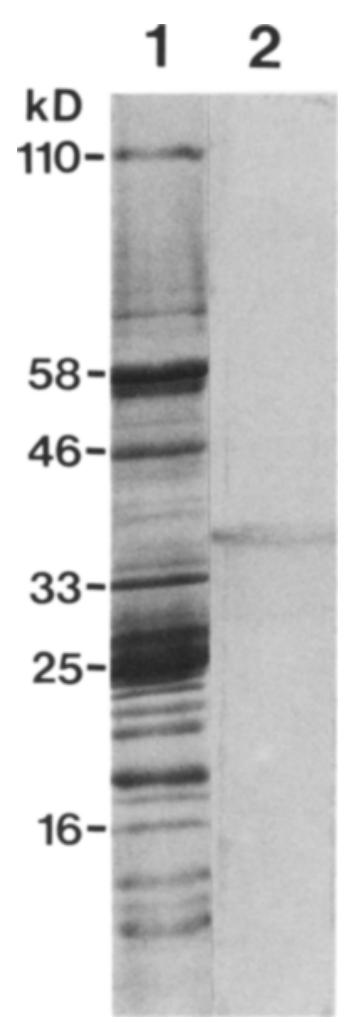

Figure 2. SDS-PAGE of malonyl-CoA:ACP transacylase purified from whole leaf extracts (2.3.4.). The separation was carried out in a system II 11-15\% linear gradient gel at $10{ }^{\circ} \mathrm{C}(18)$. Malonyl-CoA:ACP transacylase was applied in lane 2, barley wild type thylakoid proteins in lane 1 (18). Proteins were visualized with Coomassie brilliant blue.

$\mathrm{NH}_{4} \mathrm{HCO}_{3}$. The fragments were eluted at a flowrate of $12 \mathrm{ml} \cdot \mathrm{hr}^{-1}$ and collected in $1 \mathrm{ml}$ fractions at room temperature.

\section{RESULTS}

\subsection{Purification and characteristics of malonyl- CoA:ACP transacylase}

The primary purpose for purifying malonylCoA:ACP transacylase was to provide an enzyme source that could be used for assaying ACP. That purification near homogeneity was achieved is shown by SDS-PAGE in Figure 1. The preparation obtained using chloroplasts as starting material (Figure 1) contains two compo- 


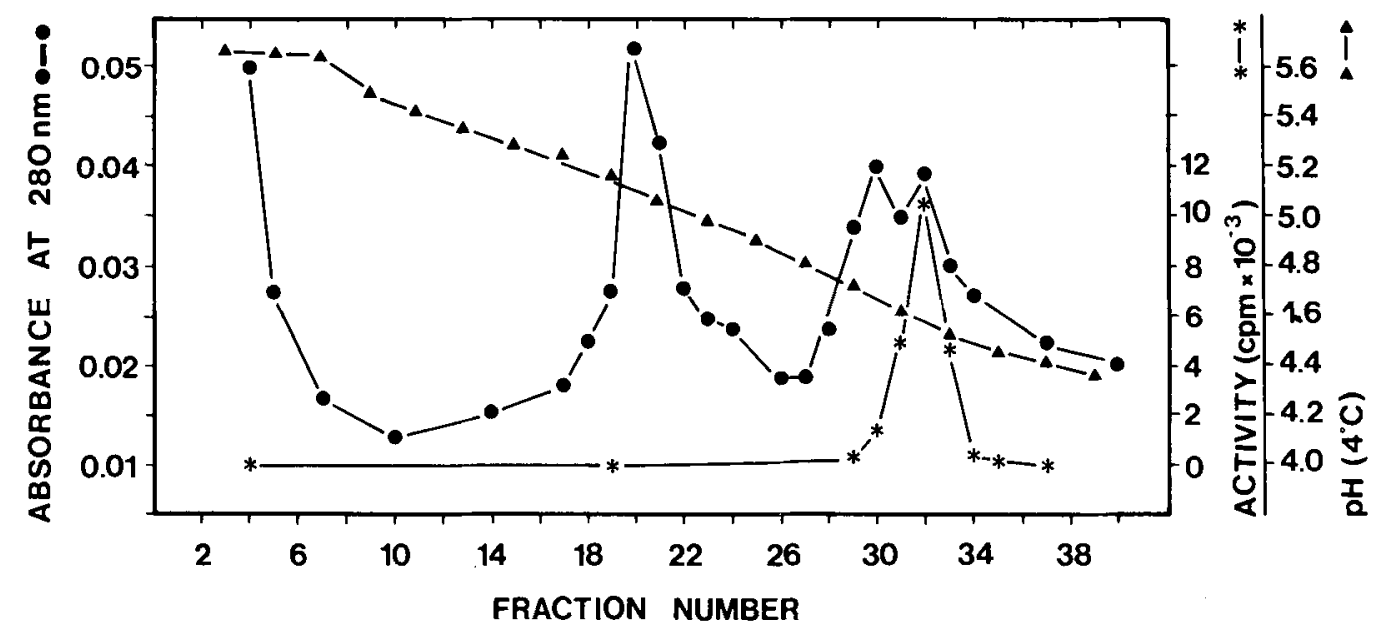

Figure 3. Purification of malonyl-CoA:ACP transacylase from isolated chloroplasts by chromatotocusing as described in 2.3.3. Enzyme activity is expressed as cpm transferred from $(2-14 \mathrm{C})$-malonyl-CoA $(1 \mathrm{nmol}=13,235 \mathrm{cpm})$ to ACP. From each $2.8 \mathrm{ml}$ fraction, $5 \mu \mathrm{l}$ were used.

nents, a major band at $M_{r} 34,500$ and an almost undetectable one at $M_{r} 43,000$ (15). When purification is started with whole leaf extracts the $\mathrm{M}_{\mathrm{r}} 34,500$ polypeptide is the only visible component (Figure 2) thus establishing the apparent mol.wt. of malonyl-CoA:ACP transacylase as 34,500 . Why the $M_{r} 34,500$ band is not sharp is unknown, but it could be due either to a modification of the protein during purification or to the presence of a contaminating polypeptide having a similar electrophoretic mobility. Intrachain sulfhydryl groups that do not remain reduced throughout the electrophoretic separation can also give rise to fuzzy bands. When the mol.wt. of partially purified malonyl-CoA:ACP transacylase from chloroplasts was determined by gel filtration chromatography (14) a value of 41,000 was obtained. Taken together these results imply that this protein is not composed of subunits. The protein as judged by chromatofocusing is relatively acidic eluting at $\mathrm{pH}$ 4.6 (Figure 3), and therefore probably has a pI slightly higher than $4.6(26)$. During the purification of malonyl-CoA:ACP transacylase from whole leaf homogenates, the activity profiles were single headed and the elution positions of enzyme activity upon gel filtration, Blue Sepharose chromatography, ion exchange and chromatofocusing were identical to those ob- tained when using chloroplast stroma proteins as starting material. These results, taken together with the SDS-PAGE, imply that only one major monofunctional malonyl-CoA:ACP transacylase is present in barley seedlings. Whether the chloroplast is the sole site of this fas component remains to be determined. The values obtained here for the studied parameters are remarkably similar to those found for the $\mathrm{E}$. coli enzyme with a mol.wt. $=35,500$ and 41,000 by SDS-PAGE and gel filtration, respectively, and a $\mathrm{pI}=4.6(33)$ as determined by isoelectric focusing. Malonyl-CoA:ACP transacylase from avocado fruits has a mol.wt. of 41,000 (7) and that from spinach a mol.wt. of 30,000 (38) as deduced from gel filtration studies. The reported differences are probably not significant. The yield of malonyl-CoA:ACP transacylase activity obtained was low, corresponding to a recovery of only $2-3 \%$, which is comparable to that reported for avocado after two column fractionations (7).

Since the activity measured in the malonylCoA:ACP transacylase assay increases linearly with the amount of ACP added up to 1.7 nmoles $(=6.8 \mu \mathrm{M})$ (Figure 4 ), the same assay procedure can be used to quantify ACP by incubating it with a known amount of malonyl-CoA:ACP transacylase and $(2-14 \mathrm{C})$-malonyl-CoA. This assay is sensitive and more convenient than the 
MALONYL-COA (n moles) $x-x$

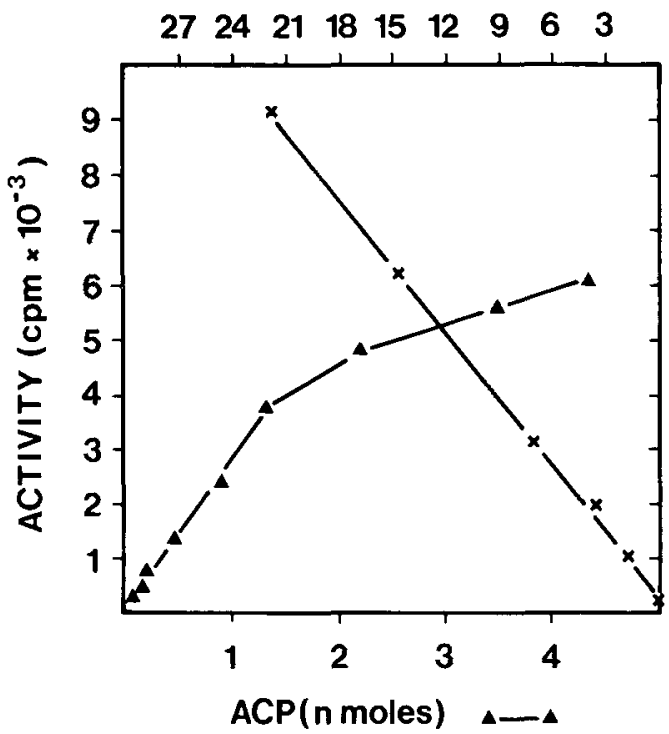

Figure 4. The dependence of malonyl-CoA:ACP transacylase activity on malonyl-CoA and ACP. $160 \mathrm{mg}$ of purified enzyme (2.3.4.) was assayed (14). In experiments with variable $\mathrm{E}$. coli $\mathrm{ACP}$ concentrations, 7.4 nmoles of $(2-14 \mathrm{C})$-malonyl-CoA $(1 \mathrm{nmol}=13,235$ cpm) were used. In experiments with variable malonyl-CoA concentrations, 4.8 nmoles of $\mathrm{E}$. coli ACP were used.

commonly used malonyl-CoA $\mathrm{CO}_{2}$-exchange reaction. The latter requires the removal of unre- acted ${ }^{14} \mathrm{CO}_{2}$ by evaporation and the action of both malonyl-CoA:ACP transacylase plus $\beta$ ketoacyl-ACP synthetase (12). The malonylCoA:ACP transacylase has the added advantage of being very stable. When stored in a crude or purified form at $-80^{\circ} \mathrm{C}$ it shows little loss of activity even after several months. The product of the malonyl-CoA:ACP transacylase reaction is malonyl-S-ACP which is characterized by its high mol.wt. and the ability to substitute for malonyl-CoA in fatty acid synthesis (14).

\subsection{Purification and properties of barley $\mathrm{ACP}$}

Following the procedure outlined in section 2.3.6., barley ACP was purified 13,000-fold from the crude leaf extract in a yield of $32 \%$ (Table I). This preparation is judged to be homogeneous by SDS-PAGE of $10 \mu \mathrm{g}$. Only one band with identical mobility to that of pure E. coli ACP is seen at $M_{r} 22,000$ (Figure 5). When $50 \mu \mathrm{g}$ were analyzed by electrophoresis some lower mol.wt. contaminants estimated to be less than $5 \%$ of the total were visible. Electrophoresis of the ACP containing preparation obtained from isolated chloroplasts (2.3.5.) shows two bands stained to the same extent (Figure 6). The mobility of the upper band is identical to that of pure $\mathrm{E}$. coli ACP and the lower band is an unknown contaminant.

In urea gels E. coli $\mathrm{ACP}$ runs corresponding to a protein with mol.wt. of $5,500(30)$ which is

Table I.

Purification of ACP from barley leaves.

\begin{tabular}{lcccc}
\hline & $\begin{array}{c}\text { Protein } \\
(\mathrm{mg})\end{array}$ & $\begin{array}{c}\text { Total } \\
\text { activity } \\
\text { (units)a) }\end{array}$ & $\begin{array}{c}\text { Purification } \\
\text { (fold) }\end{array}$ & $\begin{array}{c}\text { Recovery } \\
\text { (\%) }\end{array}$ \\
\hline Crude extract & 63000 & $48.4 \mathrm{~b})$ & - & - \\
Acid precipitate & n.d. & 48.4 & - & 100 \\
DEAE-Sepharose & 221 & 54.4 & 320 & 112 \\
DE 52 & 47 & 36.3 & 1013 & 75 \\
Sephacryl S-200 & 8.5 & 30.2 & 4595 & 62 \\
Chromatofocusing & n.d. & 21.2 & - & 44 \\
DEAE-Sepharose and & & & & 32 \\
acid precipitation & $1.5 \mathrm{c})$ & 15.1 & 13440 & 32 \\
\hline
\end{tabular}

a) $\mathrm{A}$ unit of activity is defined as the formation of $1 \mathrm{nmol}$ of $(2-14 \mathrm{C})-$ malonyl-S-ACP $\cdot \mathrm{min}^{-1}$.

b) The activity in the crude extract was too low to be determined reliably. To estimate the extent of purification, the total activity found in the initial acid precipitate was set equal to that present in the crude extract.

c) Determined by amino acid analysis.

n.d. = not determined. 


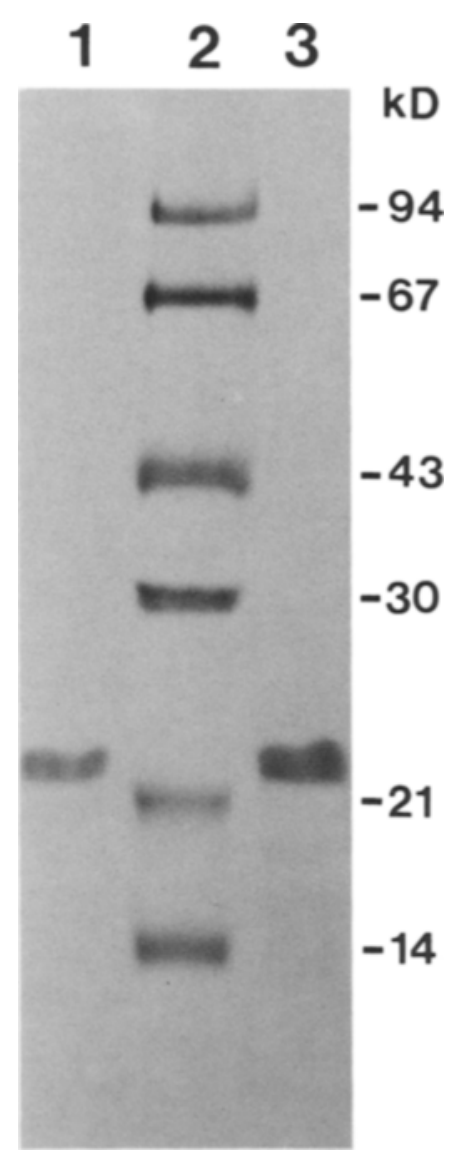

Figure 5. SDS-PAGE of ACP purified from whole leaf extracts (2.3.6.). The separation was carried out in a system II $11-15 \%$ linear gradient gel at $10^{\circ} \mathrm{C}(18)$. E. coli ACP $(10 \mu \mathrm{g})$ was electrophoresed in lane 1 , marker proteins (phosphorylase B, BSA, ovalbumin, carbonic anhydrase, soybean trypsin inhibitor and lysozyme) in lane 2 and barley ACP $(10 \mu \mathrm{g})$ in lane 3 . Proteins were visualised with Coomassie brilliant blue.

closer to the mol.wt. of 8,847 calculated from its primary structure (41). Spinach ACP with a mol.wt. of 10,300 according to sedimentation analysis had the same electrophoretic mobility as E. coli ACP upon SDS-PAGE (39). When gel filtrated on Sephadex G-100 barley ACP elutes after chymotrypsinogen (mol.wt. 25,000) but before cytochrome c (mol.wt. 11,000) with an apparent mol.wt. of $15-16,000$. The discrepancies between the true mol.wt. of $\mathrm{ACP}$ and that estimated from SDS-PAGE or gel filtration have been attributed (30) to the acidic nature of ACP

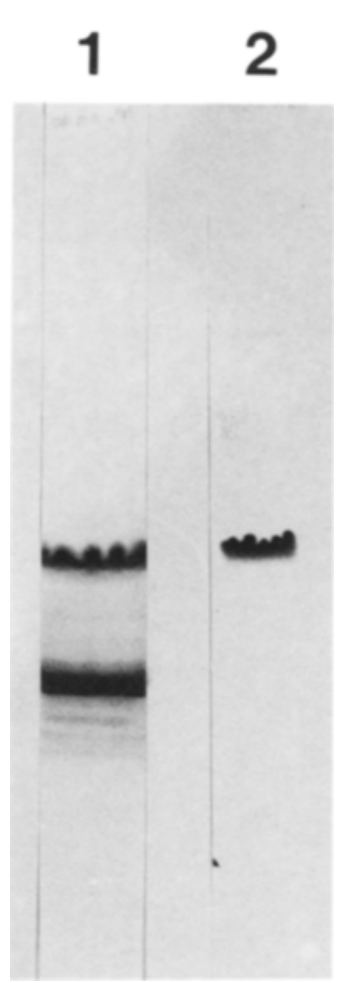

Figure 6. SDS-PAGE of ACP purified from isolated chloroplasts (2.3.3.). The separation was carried out in a system II $11-15 \%$ linear gradient gel at $10{ }^{\circ} \mathrm{C}(18)$. Barley ACP was electrophoresed in lane 1 , E. coli ACP in lane 2. Proteins were visualised with Coomassie brilliant blue.

(E. coli : (pI 4.2) (30), L. plantarum : (pI 3.8) (34)). This explanation presumably applies to the barley ACP which is also acidic, eluting at $\mathrm{pH}$ 3.75 upon chromatofocusing (Figure 7).

Barley ACP is perfectly stable to acid and retains $70 \%$ of its activity after heating at $90^{\circ} \mathrm{C}$ in $10 \mathrm{~mm}$-phosphate buffer ( $\mathrm{pH} \mathrm{7.5)}$ for $5 \mathrm{~min}$. In this aspect it is comparable to E. coli, spinach and avocado ACPs (39) but different from $\mathrm{My}$ coplasma (32) and E. gracilis ACPs (8).

Just as observed for ACP from a chloroplast extract (14), a two headed curve of ACP activity was obtained when material from whole leaves was fractionated by ion exchange chromatography on DEAE-Sepharose CL 6B. In both cases the peak eluting first was the largest and constituted some $80 \%$ of the total ACP activity. The 


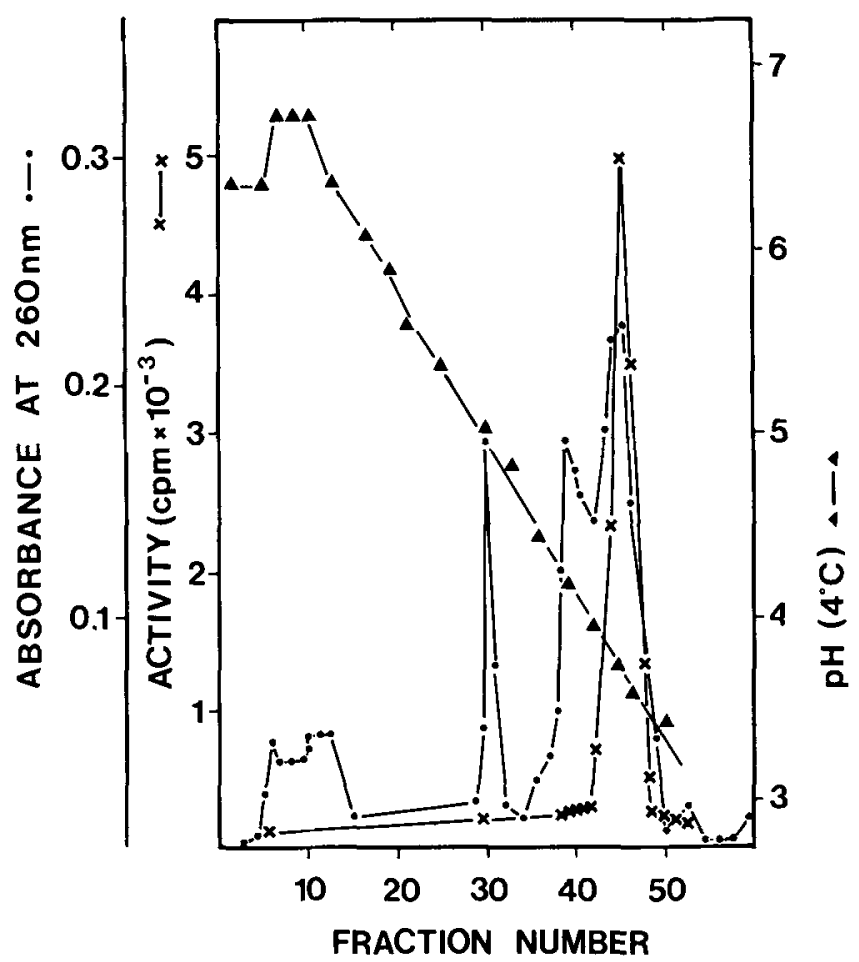

Figure 7. Chromatofocusing of barley ACP from whole leaf extracts performed as in section (2.3.6.). Activity is expressed as cpm fixed in $(2-14 \mathrm{C})$-malonyl-ACP. From each $3.9 \mathrm{ml}$ fraction, $20 \mu \mathrm{l}$ were used. $1 \mathrm{nmol}=13,235 \mathrm{cpm}$.

data indicates the possible existence of two species of ACP in the barley primary leaf tissue. Since the ratio of the two peak sizes was similar whether chloroplasts or whole leaves served as material, it is not possible to attribute them to different cell organelles. Matsumura and STUMPF (22) previously suggested the presence of two species of ACP in spinach leaf as evidenced by the existence of two peptic peptides, S4B (70\%) and S5 (30\%), containing ${ }^{14} \mathrm{C}$-iodoacetamide labelled 4'-phosphopantetheine. They suggested the critical difference to be the substitution of a lysine residue in $\mathrm{S} 4$ for a glutamic acid residue in $\mathrm{S} 5$. At neutral $\mathrm{pH}$ the ACP species containing $\mathrm{S} 4 \mathrm{~B}$ would thus elute from an anion exchange column at lower salt concentration than would the S5 containing counterpart. An analogous difference can be invoked to explain the two barley peaks. The validity of this hypothesis will be best tested at the DNA level given the small amount of barley ACP obtainable.

The average yield of barley leaf $A C P$ was $2 \mathrm{mg}$ per $10 \mathrm{~kg}$ of material processed. Since the recov- ery of ACP activity from the initial acid precipitate to the final step is $32 \%$ (Table I), the low yield is presumably due either to losses during the extraction and/or acid precipitation steps or to the very low amounts of $\mathrm{ACP}$ present in the plant tissue as compared with $\mathrm{E}$. coli from which we typically obtain $60-80 \mathrm{mg}$ of pure ACP per $\mathrm{kg}$. $\mathrm{ACP}$ from $\mathrm{E}$. coli is known to be loosely associated with the plasma membrane (4). That barley ACP is more firmly attached to membraneous material, and hence not removed in the initial homogenization procedure is unlikely because of its highly hydrophilic nature and the inclusion of $0.5 \mathrm{M}-\mathrm{NaCl}$ in the homogenization buffer which should facilitate solubilization of peripheral membrane proteins bound by electrostatic forces (26). The yield of ACP obtained here was $25 \%$ of that reported for spinach (39). This relationship is similar to that for ribulose bisphosphate carboxylase and inside-out photosystem II vesicles (C. POULSEN and B.L. Møller, pers. commun.). The reason for the lower barley yields is probably the high fiber content of the leaves which makes 
homogenization, and thereby efficient extraction, more difficult than in spinach. If this is true then the concentration of ACP in barley leaves is approximately 150 times less than in $\mathrm{E}$. coli as was estimated in spinach (22). Supporting the contention of a lower ACP concentration in plants is the observation that $\mathrm{K}_{\mathrm{m}}$ values of $A C P$ derivatives for plant fas component enzymes are much lower than that of their bacterial counterparts (37).

Some activity may be lost at the acid precipitation step (Table I). ACP from barley, as that from avocado (39), was more difficult to precipitate at pH 1.0 than that from E. coli. To obtain the reported recoveries of barley $\mathrm{ACP}, \mathrm{BSA}$ was added as a carrier and the $\mathrm{pH}$ adjusted to 1.0 before adding $\left(\mathrm{NH}_{4}\right)_{2} \mathrm{SO}_{4}$ to $100 \%$ saturation. Precipitation at $\mathrm{pH} 3.7$, but otherwise under identical conditions, gave only $25 \%$ recovery as compared to that at $\mathrm{pH} 1.0$.

If the in vivo organization of fas component enzymes resembles that of a multifunctional complex with ACP as its core (14), one might expect to find equimolar amounts of these components and $A C P$ in the whole cell preparations. The relatively lower yield of malonyl-CoA:ACP transacylase compared with the yield of $\mathrm{ACP}$ (approx. $320 \mu \mathrm{g}$ (9 nmoles) vs $2.0 \mathrm{mg}$ (206 nmoles) per $10 \mathrm{~kg}$ ) obtained in this work is in apparent disagreement with this idea. A similar relationship, however, is found in E. coli where $7.5 \mathrm{mg}$ of pure malonyl-CoA:ACP transacylase (recovery of activity $=39 \%$ ) (33) and $116 \mathrm{mg}$ of ACP (recovery of activity $=33 \%)(19)$ has been obtained per kg of E. coli processed. Since ACP plays a role in several other metabolic transformations such as phospholipid biosynthesis (10) and fatty acid desaturation (24), however, it is conceivably required in larger amounts than other fas components.

\subsection{Barley ACP in fatty acid synthesis}

As observed earlier with a five-fold purified barley chloroplast fas and partially purified barley ACP (14), the barley leaf and E. coli ACPs

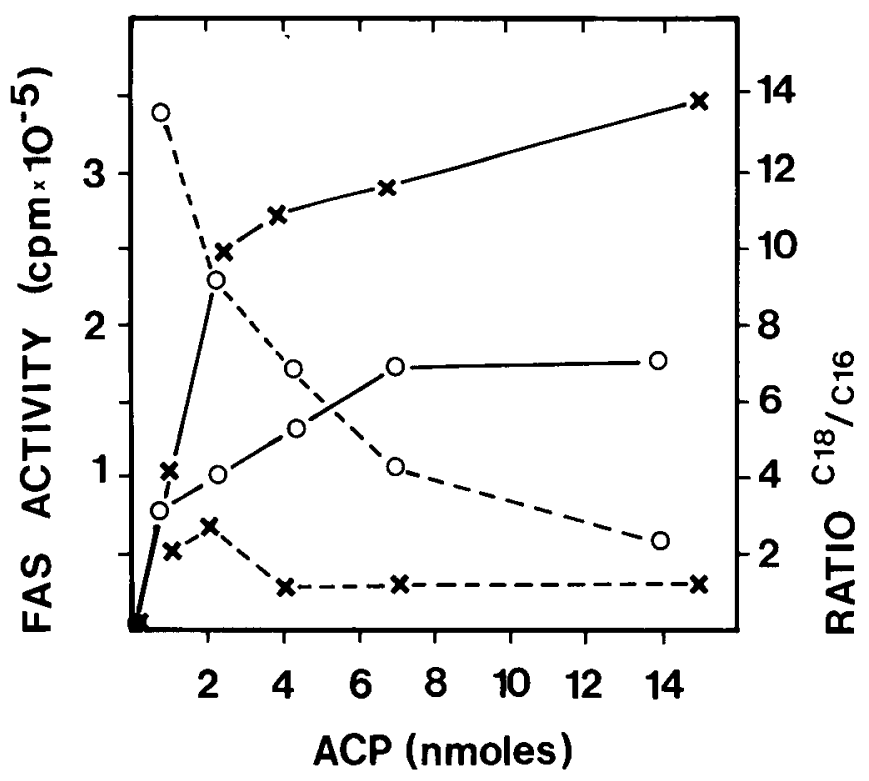

Figure 8. The effect of ACPs from E. coli and barley on fatty acid synthesis. The assay using barley chloroplast fatty acid synthetase partially purified by $\left(\mathrm{NH}_{4}\right)_{2} \mathrm{SO}_{4}$ precipitation was done as described in section 2.4 . with varying concentrations of E. coli ( $x-x)$ and barley ACP (o-o) purified to homogeneity (Figure 5). The $C_{18} / C_{16}$ ratios obtained with $\mathrm{E}$. coli $(\mathrm{x}-\mathrm{x})$ and barley $\mathrm{ACP}(\mathrm{o}-\mathrm{-}-\mathrm{o})$ were determined by radio-gas liquid chromatography and are based on a minimum of $1,218 \mathrm{cpm}$ in $\mathrm{C}_{16}$. 
Table II.

Amino acid compositions of acyl carrier proteins from several sources.

\begin{tabular}{|c|c|c|c|c|c|c|c|c|}
\hline Amino acid & $\begin{array}{l}\text { Hordeum } \\
\text { vulgarea) }\end{array}$ & $\begin{array}{c}\text { Spinacia } \\
\text { oleracea } \\
\left.(39)^{b}\right)\end{array}$ & $\begin{array}{l}\text { Persea } \\
\text { americana } \\
(39)\end{array}$ & $\begin{array}{l}\text { Euglena } \\
\text { gracilis } \\
(8)\end{array}$ & $\begin{array}{l}\text { Mycobacterium } \\
\text { smegmatis } \\
\text { (23) }\end{array}$ & $\begin{array}{l}\text { Escheri- } \\
\text { chia coli } \\
\quad(41)\end{array}$ & $\begin{array}{l}\text { Arthrobac- } \\
\text { ter viscosus } \\
\quad(39)\end{array}$ & $\begin{array}{l}\text { Clostridium } \\
\text { butyricum } \\
\text { (2) }\end{array}$ \\
\hline Cys & $(1.3)$ c) 1 & 0 & 1 & 0 & 0 & 0 & 0 & 0 \\
\hline Asp & $(8.5) \quad 9$ & 12 & 12 & 7 & 11 & 9 & 14 & 13 \\
\hline Thr & $(7.6) \quad 8$ & 6 & 7 & 3 & 5 & 6 & 2 & 1 \\
\hline Ser & (3.9) 4 & 4 & 10 & 7 & 5 & 3 & 5 & 3 \\
\hline Glu & $(14.6) 15$ & 16 & 22 & 15 & 20 & 18 & 10 & 14 \\
\hline Pro & (2.6) 3 & 2 & 3 & 3 & 4 & 1 & 1 & 1 \\
\hline Gly & $(4.0) \quad 4$ & 4 & 7 & 4 & 6 & 4 & 5 & 1 \\
\hline Ala & $(10.9) 11$ & 9 & 11 & 9 & 13 & 7 & 12 & 6 \\
\hline Val & $(8.6) \quad 9$ & 7 & 10 & 6 & 8 & 7 & 6 & 7 \\
\hline Met & (2.6) 3 & 1 & 1 & 2 & 1 & 1 & 1 & 4 \\
\hline Ile & (3.7) 4 & 5 & 5 & 8 & 6 & 7 & 6 & 8 \\
\hline Leu & $(6.0) \quad 6$ & 7 & 9 & 8 & 8 & 5 & 6 & 7 \\
\hline Tyr & $(0.2) \quad 0$ & 0 & 1 & 0 & 2 & 1 & 0 & 1 \\
\hline Phe & $(1.7) 2$ & 2 & 3 & 2 & 2 & 2 & 3 & 3 \\
\hline His & $(0.3) \quad 0$ & 1 & 1 & 0 & 0 & 1 & 1 & 2 \\
\hline Lys & (7.6) 8 & 9 & 10 & 7 & 5 & 4 & 5 & 4 \\
\hline Arg & $(0.0) \quad 0$ & 0 & 1 & 9 & 3 & 1 & 1 & 0 \\
\hline Trp & $-0 \mathrm{~d})$ & - & - & - & - & 0 & - & - \\
\hline$\beta-\mathrm{Ala}$ & $\begin{array}{ll}(0.9) \quad 1 \\
\end{array}$ & 1 & 1 & 1 & 1 & 1 & 1 & 1 \\
\hline $\begin{array}{l}\text { Total } \\
\text { exclusive } \\
\beta-\text { Ala }\end{array}$ & 87 & 85 & 114 & 90 & 89 & 77 & 78 & 75 \\
\hline $\mathrm{NH}_{3}$ & - & 9 & 10 & - & - & 6 & 5 & - \\
\hline \multicolumn{9}{|c|}{$\begin{array}{l}\text { a) Calculated on the basis of six leucine residues per molecule. } \\
\text { b) References given in parantheses. } \\
\text { c) Determined as pyridylethyl cysteine. } \\
\text { d) Determined spectrophotometrically (see Figure 9A). }\end{array}$} \\
\hline
\end{tabular}

isolated herein gave identical saturated products, predominantly myristic, palmitic and stearic acids, when incubated with $\left(\mathrm{NH}_{4}\right)_{2} \mathrm{SO}_{4}$ precipitated barley chloroplast fatty acid synthetase (14), acetyl-CoA, malonyl-CoA, NADH and NADPH. The E. coli ACP, however, was far more active in fatty acid synthesis (Figure 8). The maximal activity obtained with barley ACP under saturating conditions was only $52 \%$ of that found with E. coli ACP. The superiority of E. coli ACP in promoting total fatty acid synthesis or malonyl-CoA $\mathrm{CO}_{2}$-exchange has been reported in a number of other systems $(2,8,39)$. In the case of spinach fas the rate limiting enzyme is acetylCoA:ACP transacylase (38). The above observations can therefore be explained by assuming that E. coli ACP is a better substrate for this en- zyme. The superiority of E. coli ACP, however, seems more general, since it is also more effective than spinach $\mathrm{ACP}$ in the malonyl- $\mathrm{CoA} \mathrm{CO}_{2}$-exchange reaction (39) which depends upon both malonyl-CoA:ACP transacylase and $\beta$-ketoacyl ACP synthetase (12). In isolated barley ACP no significant amounts of apo-ACP are present (section 3.4), thus competetive inhibition by the latter cannot explain the lower activity of the purified barley ACP. Another observation, that we choose not to speculate upon at present, is that the ratio of stearic to palmitic acid synthesized by the barley chloroplast fas was strongly dependent upon the concentration of barley ACP (Figure 8 ) but not of E. coli ACP (Figure 8 and reference 14). 

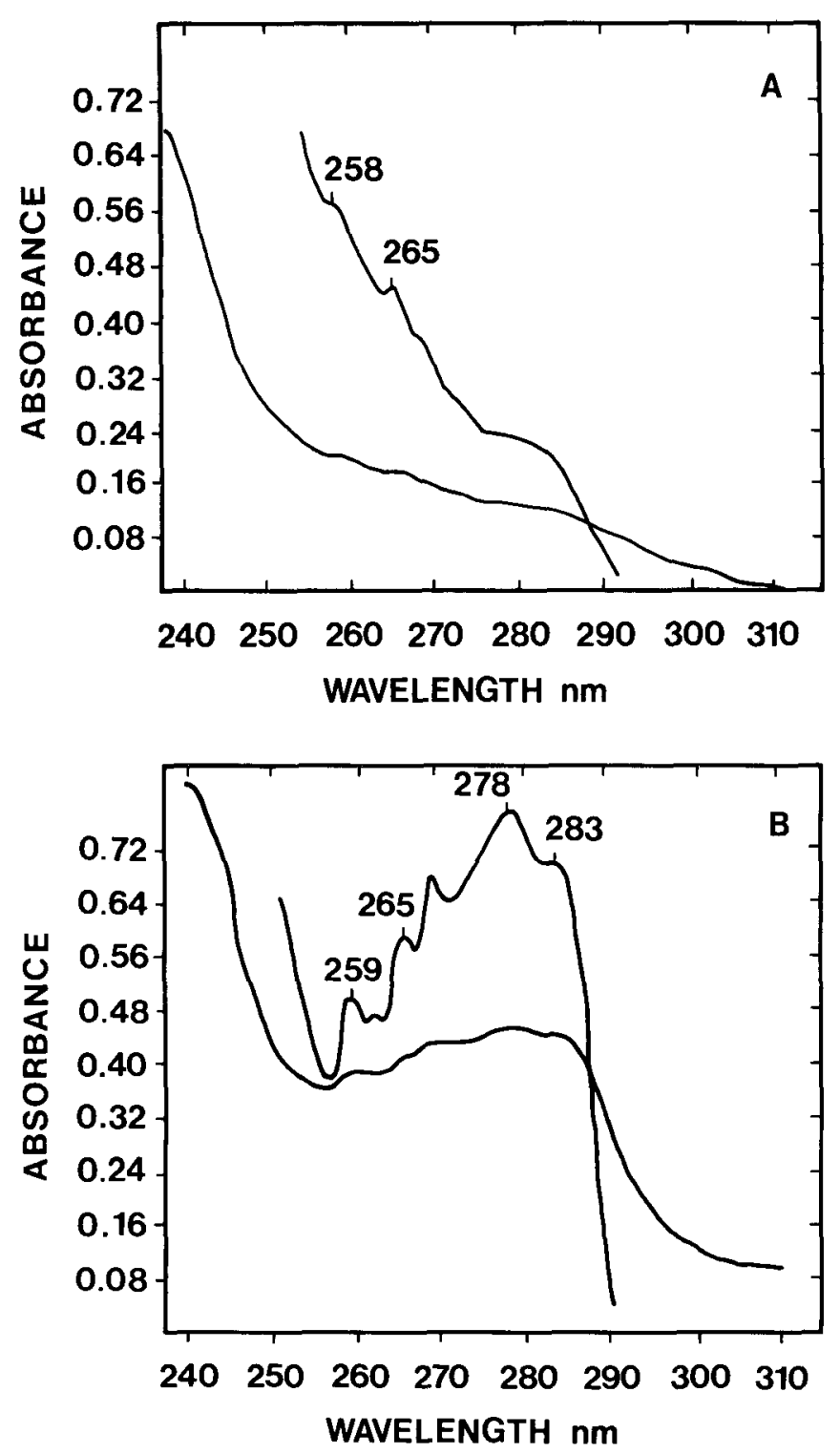

Figure 9: Absorption spectrums of ACP from different sources. A : Barley leaf ACP (Figure 5, lane 3) in water at pH 7.0. B : E. coli ACP (Figure 5, lane 1) in $0.01 \mathrm{M}$-sodium phosphate buffer at pH 7.0. An Aminco Chance DW-2A recording spectrophotometer was used. The upper traces are recorded with five times expanded scales.

\subsection{Amino acid composition of barley ACP}

The amino acid composition of barley ACP is given in Tabel II where it is compared with the compositions of ACPs from other species. As for all other ACPs, when performic acid oxidation was carried out prior to acid hydrolysis, taurine derived from 2-mercaptoethylamine was found. Combined with the presence of $\beta$-alanine this observation infers that 4'-phosphopantetheine serves as the prosthetic group. Furthermore, since the number of amino acid residues per $\beta$ alanine residue in acid precipitated ACP is 89 , 
significant amounts of apo-ACP cannot be present in the preparation. Performic acid oxidation further revealed the presence of cysteine, and hydrolysis of 2-vinylpyridinated barley ACP indicated the presence of 1.3 residues of cysteine per molecule, making barley leaf ACP similar to that of avocado. Since all other ACPs given in Table II lack cysteine, this amino acid is unlikely to serve as an acyl carrier. This supposition has been established (39) for the malonyl-radical. However, in the multifunctional polypeptide fas from pigeon liver, for example, the peripheral sulphhydryl group contributed by cysteine is loaded with all the intermediates of fatty acid synthesis except the malonyl-radical (28).

As the other ACPs that from barley is rich in hydrophilic amino acids (Table II) which is reflected in a high polarity index of $51 \%$. E. coli ACP is more acidic than plant ACPs, which is also reflected in its much firmer binding to anion exchangers (39). One can extend this observation by noting that the most marked difference between the four plant and four bacterial ACPs (Table II) is the increased number of lysine and/ or arginine residues in the former at the expense of the glutamine/glutamic acid residues. While it has been speculated that the Lys-Glx differences in spinach vs E. coli are positional (39), this cannot be true for barley as shown below.

Barley ACP is characterized by the absence of the four amino acids, tyrosine, histidine, arginine and tryptophan. In Figure 9 the u.v. spectrum of barley ACP is compared to that of $E$. coli. The absorption maximum of E. coli ACP at $278 \mathrm{~nm}$ is due to its single tyrosine residue while the contribution of the two phenylalanine residues is only detectable by the peaks at 257 and $262 \mathrm{~nm}$. Inspection of the barley ACP absorption curve reveals the absence of tyrosine and tryptophan which should give a shoulder at 288 $\mathrm{nm}$. The presence of phenylalanine is indicated by the two maxima at $258 \mathrm{~nm}$ and $264 \mathrm{~nm}$. The roughness of both spectral lines is probably caused by nucleotides and other proteins present in trace amounts. On the basis of the amino acid composition and given six leucines per molecule, barley ACP is calculated to contain 87 amino acid residues (Table II) and thus to have an approximate mol.wt. of 9,700 which compares well with the value of 9,560 deduced for spinach ACP (39). The use of such a method for calculation of mol.wts. is open to some uncertainty, however, since E. coli ACP, for example, was independently reported to be composed of 88 (39) and 86 (20) amino acids while elucidation of the complete primary structure revealed the presence of only 77 residues (41).

\subsection{Amino acid sequencing of barley ACP}

Initially $0.7 \mathrm{mg}$ of barley leaf ACP was applied to the sequenator. Except for residue 18 the sequence could be assigned with certainty from the $\mathrm{N}$-terminal end through the first 54 steps. The first degradation cycle yielded more than $95 \%$ alanine-PTH (approx. 83 nmoles) which corresponds to approx. 1 nmole of $\mathrm{N}$-terminal alanine per 80 nmoles of amino acids applied to the sequenator. This is in good agreement with the 87 residues per molecule estimated from the compositional analysis. The residue in position 18 may be cysteine (Figure 10, ref. 30), since the protein was not derivatized before sequencing and since no other "holes" were found later in the sequence up to position 72 . The presence of cysteine between positions 72 and 87 cannot be ruled out, however, as a definitive amino acid composition of $\mathrm{CNBr}$ fragment IV was not obtained.

After cyanogen bromide cleavage gel filtration was used to separate the resulting fragments produced (Figure 11). Four peptide pools (A, B, C, and $D$ ) were collected. As the initial sequencing had revealed the position of all three methionine residues (Figure 10), the carboxy terminal fragment IV should have the sequence $\mathrm{H}_{2} \mathrm{~N}$-GlyLeu-Glu-Glu-. Fragment I should have the sequence $\mathrm{H}_{2} \mathrm{~N}$-Ala-Ala-, fragment III the sequence $\mathrm{H}_{2} \mathrm{~N}$-Ile-Val-Lys-Lys, and fragment Il the sequence $\mathrm{H}_{2} \mathrm{~N}$-Gly-Glu-Ala-. Sequence analysis of the pools $\mathrm{A}, \mathrm{B}$ and $\mathrm{C}$ plus amino acid analysis of pool $D$ revealed the following: Pool $C$ was almost exclusively fragment II. Pool D was probably fragment I plus 4'-phosphopantetheine or a modified form thereof. Fragment III was the main component of pool A. Despite the symmetrical appearance of the elution profile of pool B, it contained $70 \%$ fragment IV plus $30 \%$ fragment III. Pool B was subjected to 19 steps of degradation which revealed the sequence of residues 54-72. The sequence so obtained agreed with 


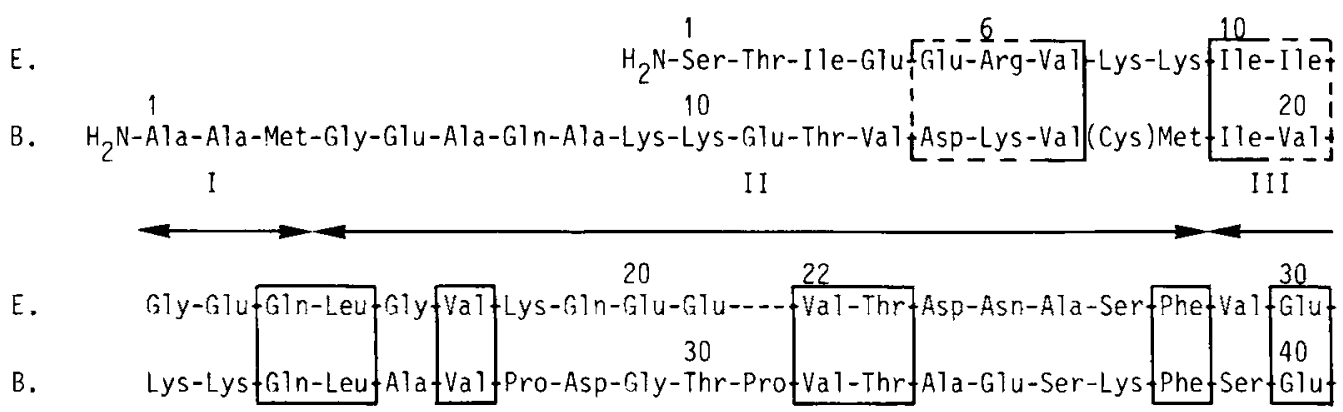

III

E.

B. $*$
Aspp
$\begin{aligned} & \text { Leu-Gly-Ala-Asp-Ser-Leu-Asp-Thr-Val-Glu-Leu-Val-Met-Ala-Leu-Glu-Glu-Glu-Phe } \\ & 41\end{aligned} \quad 50$
Leu-Gly-Ala-Asp-Ser-Leu-Asp-Thr-Val-Glu-Ile-Val-Met-Gly-Leu-Glu-Glu-Glu-Phe

E.

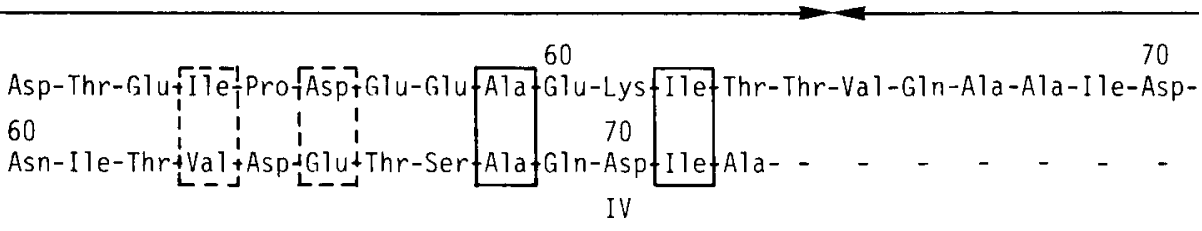

E.

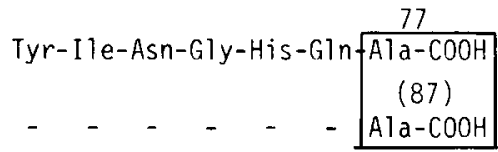

IV

Figure 10. Comparison of the amino acid sequences of barley leaf $A C P(B)$ and $E$. coli $A C P(E)$. The sequences have been aligned and gaps (---) introduced to maximize homology. Numbers of the amino acid positions are given above the individual ACPs. Residues which are invariant in the two molecules are enclosed in boxes, conservative replacements are enclosed with broken lines. Brackets indicate uncertainty. I, II, III, IV = barley ACP cyanogen bromide fragments. Asterisk $=4^{\prime}$-phosphopantetheine attachment site.

that determined in a preliminary experiment, where the whole $\mathrm{CNBr}$ mixture was applied to the cup without prior fractionation. In both cases the repetetive yield drastically decreased from residues $69-72$ and sequencing beyond Ala - 72 was not possible. This decrease in efficiency is presumed due to losses of the remaining peptides during the organic washes. Attempts to purify CNBr fragment IV completely free of $\mathrm{CNBr}$ fragment III were made by gel filtration and ion exchange chromatography. Neither was successful.
Digestion of barley ACP from its C-terminus by carboxypeptidase $\mathrm{Y}$ led only to the release of alanine (Figure 12) which therefore is assigned as the C-terminal residue. ABITA et al. (1) incubated E. coli ACP with carboxypeptidase $A$ which also led to the release of alanine, whereas MAJERUS (20) under apparently identical conditions observed release of histidine and glutamine in addition.

If the number of amino acids per molecule given in Table II is correct, a tentative composition of the remaining $13-15$ amino acids in frag- 


\section{GEL FILTRATION OF CYANOGEN BROMIDE FRAGMENTS}

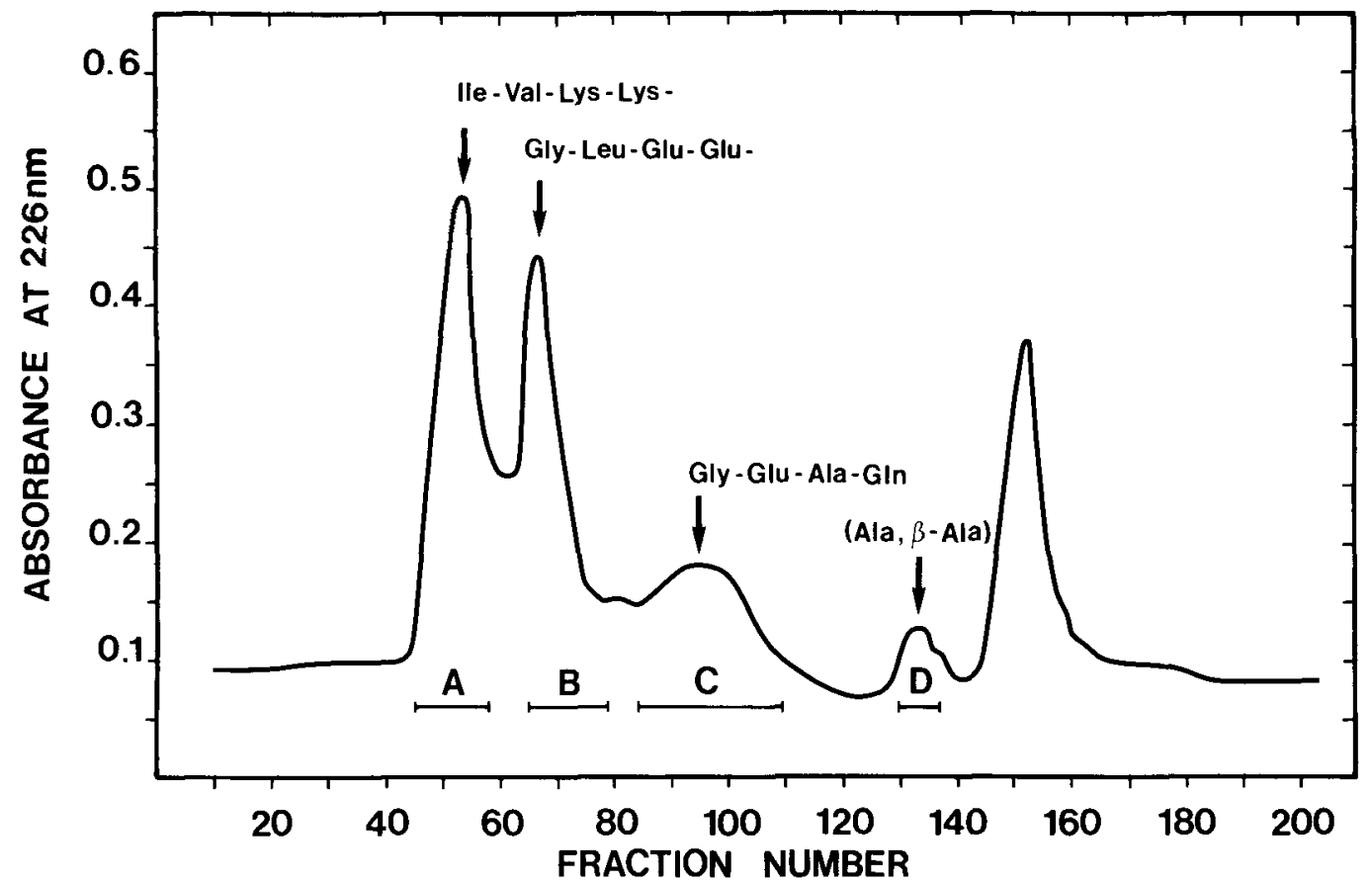

Figure 11. Separation on Biogel $\mathrm{P} 30$ of peptides obtained by $\mathrm{CNBr}$ cleavage of purified barley leaf $\mathrm{ACP}$ as described in 2.7. Fractions included in the four pools (A, B, C and D) were used for further analysis.

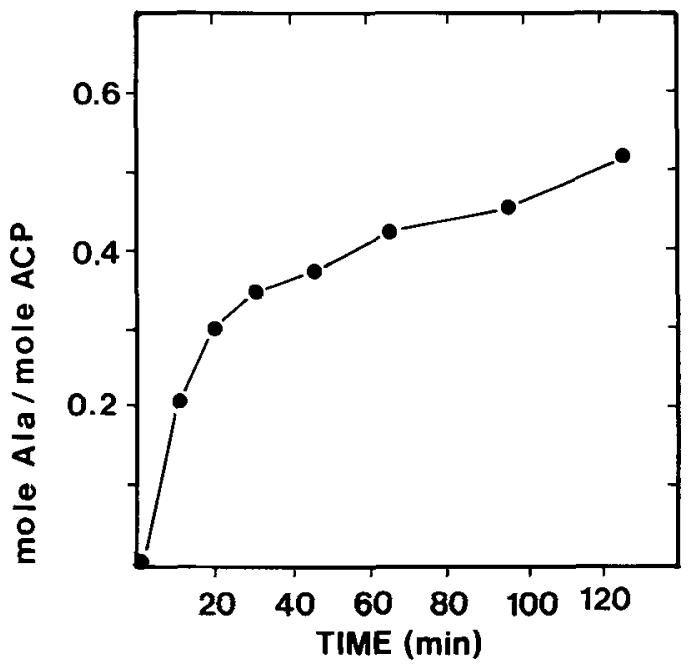

Figure 12. Time course of carboxypeptidase $Y$ digestion of purified barley leaf ACP. Only alanine was released. ment IV can be made. As no tryptophan, tyrosine, arginine, histidine, phenylalanine, isoleucine, methionine, glycine or serine should be present, the composition becomes ( $\mathrm{Asx}_{1-2}, \mathrm{Thr}_{2}$, $\mathrm{Glx}_{2-3}, \mathrm{Pro}_{1}, \mathrm{Ala}_{1}, \mathrm{Val}_{2}, \mathrm{Leu}_{2}, \mathrm{Lys}_{2}$ )-Ala-COOH. This barley composition can be compared to the corresponding E. coli one $\left(\mathrm{Asp}_{1}, \mathrm{Asn}_{\mathrm{l}}, \mathrm{Thr}_{1}\right.$, $\mathrm{Gln}_{2}, \mathrm{Gly}_{1}, \mathrm{Ala}_{2}, \mathrm{Val}_{1}, \mathrm{Ile}_{2}, \mathrm{Tyr}_{1}, \mathrm{His}_{1}$ )-Ala$\mathrm{COOH}$ (41). On the basis of this collation plus Figure 10, a marked difference in the C-terminal amino acid compositions of barley and $\mathrm{E}$. coli ACPs becomes evident.

\section{DISCUSSION}

When the sequences of barley leaf and $\mathrm{E}$. coli ACP are aligned to give maximal homology (Figure 10), the differences in primary structure are greatest at the ends of the polypeptide. Most striking is the extension of the $\mathrm{N}$-terminal part of 
Table III.

Comparison of primary sequences of 4-phosphopantetheine peptides

E.coli (41)

Arthrobacter (22)a)

Barley

Spinach (22)a)

Rat liver (32)

Yeast (35)
-Ser-Phe-Val-Glu-Asp-Leu-Gly-Ala-Asp-Ser-Leu-Asp-Thr-Val-Glu-Leu-Val-Met-

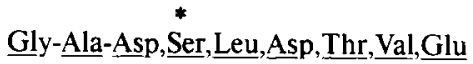

*

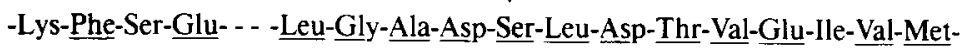

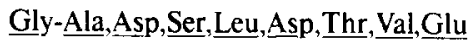

*

-Ser-Leu-Asx-Leu-Gly-Glx-Gly-Glu-Asp-Ser-Leu

Gly-Gly-Lys-

The asterisks denote the serine to which the 4 -phosphopantheteine is bound.

a) Suggested on the basis of partial Edman degradation and compositional analyses.

barley $\mathrm{ACP}$ with the sequence $\mathrm{H}_{2} \mathrm{~N}$-Ala-AlaMet-Gly-Glu-Ala-Gln-Ala-Lys-, corresponding to a mol.wt. of 857 which compares well with the slightly higher mol.wt. of plant ACPs than of bacterial ACPs observed whenever the proper comparisons have been made (section 3.4). Despite the noted differences, homology between $\mathrm{E}$. coli and barley leaf ACP is outspoken, especially in the region containing the 4'-phosphopantetheine attachment site (Figure 10). With the alignment chosen here (Figure 10), 18 out of 20 (21) residues are invariant from Gin - 40 to Phe 59 of barley ACP, while 21 of the 34 amino acid substitutions in the sequence Lys - 10 to Ala - 72 can be due to single base changes. The introduction of a single residue gap in each protein reveals that overall 29 of the $73(40 \%)$ sequenced residues are invariant and an additional six replacements are conservative (Figure 10). An analogous situation emerges when the primary structure of the ribosomal L12 protein from E. coli is compared to the L12 ribosomal protein from spinach chloroplasts. The spinach protein was ten residues larger and the amino acid homology was least pronounced in the $\mathrm{N}$-terminal region (20\%) which should be compared to an over-all homology of $49 \%$ (3). The barley leaf and E. coli ACP are also similar in having an abundance of negatively charged carboxyl residues in the central region (residues 23-72, barley), while the basic amino acids are clustered in the peripheral regions (residues 9-22 and 73-87 of barley).

The amino acids adjacent to the prosthetic group bearing serine residue are known for the ACPs from six sources (Table III). The sequences of rat liver and yeast ACPs, which unlike the others are part of multifunctional polypeptide chains, differ significantly. Nevertheless, one observes in all cases as predicted by the CHOU and FASSMAN algorithms, that the fourth position of a beta turn from the glycine residue is occupied by the prosthetic group carrying serine residue (30). As the function of ACP in fatty acid synthesis is analogous to that of $\mathrm{COA}$ in fatty acid oxidation its role is much like that of a coenzyme. The same coenzyme participates in a number of different enzymes. Thus mutation leading to a change in the structure of a coenzyme could require simultaneous mutation of all interacting enzymes in order to preserve all activities. Such reasoning has been invoked to explain why coenzymes apparently do not evolve (16). Seen in this light the high degree of conservation of the sequences around the prosthetic groups of the various ACPs (Table III) is to be expected.

With the elucidation of the primary structure of E. coli ACP, two lines of experiments $(1,12,20$, $21,36)$ have been performed to delineate those parts of the polypeptide other than that bearing the 4'-phosphopantetheine moiety that are in- 
P.B. Høנ \& I. Svendsen: Barley acyl carrier protein

Table IV

Summary of the investigated structural - functional relationships of E. coli ACP

\begin{tabular}{|c|c|c|c|c|c|c|}
\hline \multirow[b]{2}{*}{$\begin{array}{l}\text { Starting } \\
\text { peptide }\end{array}$} & \multirow[b]{2}{*}{$\begin{array}{l}\text { Residues } \\
\text { affected }\end{array}$} & \multirow[b]{2}{*}{$\begin{array}{c}\text { Type of alteration } \\
\text { (refs) }\end{array}$} & \multicolumn{3}{|c|}{ Biological functions tested a) } & \multirow{2}{*}{$\begin{array}{l}\text { Other } \\
\text { observationsc) }\end{array}$} \\
\hline & & & Fas & $\begin{array}{c}\text { Malonyl- } \mathrm{CO}_{2} \\
\text { exchange }\end{array}$ & $\begin{array}{l}\text { holo-ACP } \\
\text { synthetase }\end{array}$ & \\
\hline 1. $\mathrm{ACP}-(1-77)$ & $75-77$ & $\begin{array}{l}\text { deleted via } \\
\text { carboxypeptidase } A \\
(20,21)\end{array}$ & 100 & 100 & 100 & \\
\hline $\begin{array}{l}\text { 2. acetylated ACP } \\
(1-77)\end{array}$ & $1-6$ & $\begin{array}{l}\text { deleted via trypsin } \\
(1,21)\end{array}$ & 0 & 0 & $<5$ & $\begin{array}{l}\text { MS lost. The pep- } \\
\text { tide does not act } \\
\text { as a competitive } \\
\text { inhibitor in the } \\
\text { malonyl- } \mathrm{CO}_{2} \text { ex- } \\
\text { change reaction. }\end{array}$ \\
\hline 3. $\operatorname{ACP}(1-77) d)$ & 6 & $\begin{array}{l}\text { nitrated } \\
(12)\end{array}$ & n.d. & 100 & 100 & \\
\hline $\begin{array}{l}\text { 4. }\left(\mathrm{Arg}\left(\mathrm{NO}_{2}\right)^{6}\right. \\
\operatorname{Nle}(8,9,18 \text {, } \\
\text { 44)-ACP(1- } \\
74) \mathrm{d})\end{array}$ & $\begin{array}{l}\text { "O" through } \\
X . X=(0,1 \\
2,4,5,6)\end{array}$ & $\begin{array}{l}\text { deleted } \\
(12)\end{array}$ & n.d. & $\begin{array}{l}(100,54,33 \\
17,5,0)\end{array}$ & $\begin{array}{l}(100,100,51, \\
34,34,1)\end{array}$ & \\
\hline $\begin{array}{l}\text { 5. }\left(\mathrm{Arg}\left(\mathrm{NO}_{2}\right)^{6}\right. \\
\mathrm{Nle}(8,9,18 \\
44)-\mathrm{ACP}(1- \\
74) \mathrm{d})\end{array}$ & $62-74$ & $\begin{array}{l}\text { deleted via trypsin } \\
\text { (12) }\end{array}$ & n.d. & 76 & 13 & \\
\hline 6. ACP-(1-77) & $\begin{array}{l}-\mathrm{COOH} \\
\text { residues }\end{array}$ & $\begin{array}{l}\text { amidated } \\
(36)\end{array}$ & 0 & n.d. & n.d. & $\begin{array}{l}2-3 \text { residues ami- } \\
\text { dated, predomi- } \\
\text { nantly in the re- } \\
\text { gion } 29-41 \text {. }\end{array}$ \\
\hline 7. ACP-(1-77) & $I, 8,9,18,6 \mathrm{I}$ & $\begin{array}{l}\text { acetylated } \\
(1,21)\end{array}$ & 100 & 80 & n.d. & MS intact \\
\hline 8. $A C P-(1-77)$ & $\begin{array}{l}\text { - } \mathrm{COOH} \\
\text { residues }\end{array}$ & $\begin{array}{l}\text { amidated } \\
\text { (1) }\end{array}$ & 0 & 0 & n.d. & $\begin{array}{l}11 \text { of } 22 \text { carboxyl- } \\
\text { ates amidated. } \\
\text { MS lost. }\end{array}$ \\
\hline 9. ACP-(1-77) & 71 & $\begin{array}{l}\text { nitirated } \\
\text { (1) }\end{array}$ & 130 & 130 & n.d. & $\begin{array}{l}\text { MS intact. Ac- } \\
\text { tivity with } \\
\text { glycerol-3-phos- } \\
\text { phate } \\
\text { acyltransferase } \\
\text { only } 33 \% \text {. }\end{array}$ \\
\hline 10. ACP-(1-77) & 44 & $\begin{array}{l}\text { alkylated } \\
\text { (1) }\end{array}$ & 30 & 80 & n.d. & $\begin{array}{l}\text { MS intact, ratio of } \\
\beta \text {-hydroxy acids } \\
\text { to saturated acids } \\
\text { decreased } 9 \text {-fold. }\end{array}$ \\
\hline 11. ACP-(1-77) & $1-18,62-77$ & $\begin{array}{l}\text { deleted via trypsin } \\
(20,21)\end{array}$ & 0 & 0 & n.d. & $\begin{array}{l}\text { Poor substrate for } \\
\beta \text {-ketoacyl ACP } \\
\text { reductase. } \\
\text { Does not act as a } \\
\text { competetive in- } \\
\text { hibitor in the mal- } \\
\text { onyl- } \mathrm{CO}_{2} \text { ex- } \\
\text { change reaction. }\end{array}$ \\
\hline 12. $\mathrm{ACP}-(1-77)$ & $45-77$ & $\begin{array}{l}\text { deleted via } \mathrm{CNBr} \\
\text { (21) }\end{array}$ & 0 & 0 & n.d. & \\
\hline
\end{tabular}

a) Activities given as percentage of activity of starting material.

b) n.d. = not determined.

c) $\mathrm{MS}$ = molecular structure as judged by optical rotatory dispersion spectra.

d) Chemically synthesized. 
volved in the successful interaction between an ACP derivative and the more than ten enzymes involved in the reactions. One approach made use of chemically and enzymatically modified ACP isolated from E. coli, the other was based on solid phase peptide synthesis of E. coli ACP and analogues thereof. Table IV summarizes the observations made, and in the following paragraphs we highlight the most significant.

The N-terminal part of E. coli ACP is of crucial importance for its activity, whereas the Cterminal region seems less critical in the assays performed. Deletion of the three C-terminal residues from ACP (line 1) was without measurable effect, while cleavage of the bond between Arg - 6 and Val - 7 (line 2) resulted in a loss of i) the native molecular structure, ii) its activity in fatty acid synthesis and iii) its ability to act as a competetive inhibitor in the malonyl-CoA $\mathrm{CO}_{2}$ exchange reaction (line 2). Furthermore, deletion of only the N-terminal serine residue (line 4) resulted in a greater loss of malonyl-pantheteine $\mathrm{CO}_{2}$ exchange activity than that observed after deletion of residues 62-74 from the C-terminus (line 5). A study of synthetic fragments (line 4) showed that loss of activity could not be attributed to a single amino acid among the six $\mathrm{N}$ terminal residues. Rather activity decreased with the loss of each additional amino acid. ABITA et al. (1) concluded that the $\mathrm{N}$-terminal residues of ACP were part of an array of non covalent interactions, each amino acid contributing by either ionic or hydrophobic interactions to maintaining an active conformation of ACP. The sensitivity of the E. coli ACP to aminopeptidase attack only under denaturing conditions, and the inaccessibility of the glutamic acid residues at positions 4 and 5 to ethylglycinate (line 6) further implies that the $\mathrm{N}$-terminal part of the protein is masked in its native state and not available for protein protein interactions.

A similar situation to that of the differential importance of the $\mathrm{N}$ - vs C-terminal parts of $\mathrm{E}$. coli ACP is found when comparing the relative importance for biological activity of the amino groups of lysine vs the carboxylic acid residues of glutamic and aspartic acids. Whereas the epsilon amino groups of the former can be acetylated without loss of biological function in vitro (Table IV, line 7), amidation of as few as two to three residues in the sequence Val - 29 to $\mathrm{Glu}$ - 41 was accompanied by a complete loss of activity in fatty acid synthesis (Table IV, lines 6 and 8). These and other observations (41) are taken to indicate, that $\mathrm{ACP}$ has an unusual high density of negatively charged side chains on its surface which are essential for the specific interaction of ACP with fatty acid synthetase components. The high degree of negatively charged residues around the prosthetic groups of both E. coli and barley leaf ACPs may play an analogous role to that of the three negatively charged phosphate residues of $C O A$.

The above summation leads to the conclusion that the marked difference in the primary structure of especially the N-terminal end of barley $A C P$ vs the $E$. coli will be reflected in a different tertiary structure. The latter will in turn alter secondary site mediated protein protein interactions during fatty acid synthesis. The higher activity in fatty acid synthesis of E. coli than barley or the previously studied spinach (39) ACPs in the respective plant fas systems (section 3.3) can be accounted for by such reasoning. This implies that at least one of the barley fas component activities has not evolved structurally to accommodate the changes in the plant ACP. Such conservation of component fas activities is suggested by the similarities described herein between the malonyl-CoA ACP transacylases from barley and E. coli.

The demonstration that only some of the antigenic determinants of the plant and E. coli ACP are common (27) implies that plant and bacterial ACPs have the potential to interact differently with individual ACP dependent enzymes. Several lines of evidence support this contention. Firstly, incubating spinach $\mathrm{ACP}$ with $\mathrm{E}$. coli fraction A completely altered the distribution of fatty acid products obtained when E. coli ACP was used (39). An extensive accumulation of unusual compounds, reported to be 3-hydroxy fatty acids, occurred at the expense of the unsaturated fatty acids (39). Thus, although the plant fas enzymes tolerate E. coli ACP and its acyl derivatives perfectly well, the plant $A C P$, in this case from spinach, is a poor substrate for one or more of the E. coli fas component enzymes, e.g. the $\beta, \gamma$-decanoylthioester dehydrase which has not been found in plants. Secondly, similar situa- 
tions of differential influence of modification of ACP on different enzymes from the same organism as the ACP are also known. That is, nitration of E. coli ACP Tyr - 71 (Table IV, line 9) reduces the activity of the ACP with glycerol-3-phosphate acyltransferase to $33 \%$, but enhances its activity with fas. Alkylation of E. coli ACP Met 44 causes only slight changes of the molecules optical rotatory dispersion spectrum, but decreases nine-fold the ratio of $\beta$-hydroxy fatty acids to saturated fatty acids synthesized (Table IV, line 10). This probably reflects the differential change of interaction of ACP with one or more of the E. coli dehydrases. These examples demonstrate that only minor structural alterations of ACP can completely change the fatty acid products. We should point out, however, that the ability to make these observations depend on the fact that $\mathrm{E}$. coli fas is complex in the sense that it contains duplicate yet funtionally different components ( $\beta$-ketoacyl ACP synthetases I \& II, plus $\alpha, \beta$ - and $\beta, \gamma$-dehydrases) which give rise to different sets of products.

The reported amino acid sequence of barley ACP makes it possible to synthesize oligonucleotides capable of specific hybridization to the structural gene(s) for this protein. The cloning of such a gene will i) by nucleotide sequencing reveal the undetermined sequence of the $C$ terminal amino acids, ii) pinpoint the site of synthesis of ACP and iii) make it feasible to elucidate the mechanisms regulating its expression.

\section{ACKNOWLEDGEMENTS}

Dr. Penny von Wettstein-Knowles is thanked for encouragement throughout this work and for a critical review of the manuscript. Thanks are also due to JøRn DalgaARd MIKkelsen, Robyn van HeEswyck and Dr. Birte SVENSSON for helpful discussions. We are grateful to Merete Petersen, Bodil Corneliussen and Lone Sørensen for excellent technical assistance. AVRIL BAyNe and NINA Rasmussen are thanked for help with figures.

\section{REFERENCES}

1. Abita, J.P., M. Lazdunski \& G.P. Ailhaud: Structure function relationships of the acyl carrier protein of Escherichia coli. Eur. J. Biochem. 23, 412-420 (1971)
2. Ailhaud, G.P., P.R. Vagelos \& H. Goldfine: Involvement of acyl carrier protein in acylation of glycerol 3-phosphate in Clostridium butyricum. J. Biol. Chem. 242, 4459-4465 (1967)

3. Bartsch, M., M. Kimura \& A.-R. SubramaNIAN: Purification, primary structure, and homology relationships of a chloroplast ribosomal protein. Proc. Natl. Acad. Sci. USA 79, 6871-6875 (1982)

4. Bosch, H. van den, J.R. Williamson \& P.R. VAGELOS: Localization of acyl carrier protein in Escherichia coli. Nature 228, 338-341 (1970)

5. BRADFORD, M.M.: A rapid and sensitive method for the quantification of microgram quantities of protein utilizing the principle of protein dye binding. Anal. Biochem. 72, 248-254 (1976)

6. CAPaldi, R.A. \& G. VAnderkol: The low polarity of many membrane proteins. Proc. Natl. Acad. Sci. USA 69, 930-932 (1972)

7. Caughey, I. \& R.G.O. Keckwick: The characteristics of some components of the fatty acid synthetase system in the plastids from the mesocarp of avocado (Persea americana) fruit. Eur. J. Biochem. 123, 553-561 (1982)

8. DiNello, R.K. \& M.L. Ernst-Fonberg: Purification and partial characterization of an acyl carrier protein from Euglena gracilis. J. Biol. Chem. 248, 1707-1711 (1973)

9. ERnst-Fonberg, M.L., F. Dubinskas \& Z.L. JoNAK: Comparison of two fatty acid synthetases from Euglena gracilis variety bacillaris. Arch. Biochem. Biophys. 165, 646655 (1974)

10. Frentzen, M., E. Heinz, T.A. McKeon \& P.K. STUMPF: Specificities and selectivities of glycerol-3-phosphate acyltransferase and monoacylglycerol-3-phosphate acyltransferase from pea and spinach chloroplasts. Eur. J. Biochem. 129, 629-636 (1983)

11. Friedman, M., L.H. Krull \& J.F. Cavins: The chromatographic determination of cystine and cysteine residues in proteins as S-beta-(4pyridyl ethyl)-cysteine. J. Biol. Chem. 245, 3868-3871 (1970)

12. HanCoCk, W.S., G.R. Marshall \& P. RoY VAGELOS: Acyl carrier protein XX. Chemical synthesis and characterization of analogues of acyl carrier protein. J. Biol. Chem. 248, 24242434 (1973)

13. HIRS, C.H.W.: Determination of cystine as cysteic acid . Meth. Enzymol. 11, 59-62 (1962)

14. HøJ, P.B. \& J.D. Mikkelsen: Partial separation of individual enzyme activities of an ACP-de- 
pendent fatty acid synthetase from barley chloroplasts. Carlsberg Res. Commun. 47, 119-141 (1982)

15. HøJ, P.B. \& J.D. Mikkelsen: Partial purification and characterization of fatty acid synthetase from barley chloroplasts. In : Biochemistry and metabolism of plant lipids. J.F.G.M. Wintermans and P.J.C. Kuiper eds., Elsevier/North Holland. Biomedical Press, Amsterdam, 17-20 (1982)

16. KAPLAN, N.O.: Concepts and significance of enzyme evolution. In: Homologous enzymes and biochemical evolution. N. van Thoai \& J. Roche, eds. Gordon and Breach, New York, London 405-432 (1968)

17. LEE, H.-M. \& J.F. RIORDAN: Does carboxypeptidase $Y$ have intrinsic endopeptidase activity? Biochem. Biophys. Res. Commun. 85, 11351142 (1978)

18. MaChOLd, O., D.J. Simpson \& B.L. Møller: Chlorophyll proteins of thylakoids from wild type and mutants of barley (Hordeum vulgare L.). Carlsberg Res. Commun. 44, 235-254 (1979)

19. Majerus, P.W., A.W. Alberts \& P.R. Vagelos: Acyl carrier protein from Escherichia coli. Methods Enzymol. XIV, 43-50 (1969)

20. MAJERUS, P.W.: Acyl carrier protein: Structural requirements for function in fatty acid biosynthesis. J. Biol. Chem. 242, 2325-2332 (1967)

21. MAJERUS, P.W.: Acyl carrier protein: Effects of acetylation and tryptic hydrolysis on function in fatty acid synthesis. Science, 159, 428-431 (1968)

22. Matsumura, S. \& P.K. StumpF: Fat metabolism in higher plants XXXV. Partial primary structure of spinach acyl carrier protein. Arch. Biochem. Biophys. 125, $932-941$ (1968)

23. Matsumura, S., D.N. Brindley \& K. Bloch: Acyl carrier protein from Mycobacterium phlei. Biochem. Biophys. Res. Commun. 38, 369-377 (1970)

24. McKeon, T.A. \& P.K. StumpF: Purification and characterization of the stearoyl-acyl carrier protein desaturase and the acyl-acyl carrier protein thioesterase from maturing seeds of safflower. J. Biol. Chem. 257, 12141-12147 (1982)

25. MiKKELSEN, J.D.: Structure and biosynthesis of beta-diketones in barley spike epicuticular wax. Carlsberg Res. Commun. 44, 133-147 (1979)

26. MøLLER, B.L. \& P.B. Høנ: A thylakoid polypeptide involved in the reconstitution of photo- synthetic oxygen evolution. Carlsberg Res.Commun. 48, 169-185 (1983)

27. OhLRogGe, J.B., D.N. KuhN \& P.K. StumpF: Subcellular localization of acyl carrier protein in leaf protoplasts of Spinacia oleracea. Proc. Natl. Acad. Sci. USA 76, 1194-1198 (1979)

28. Phillips, G.T., J.E. Nixon, J.A. DORSEY, P.H.W. Butterworth, C.J. Chesterton \& J.W. PORTER: The mechanism of synthesis of fatty acids by the pigeon liver enzyme system. Arch. Biochem. Biophys. 138, 380-391 (1970)

29. Rasmussen, S.K., H.E. Hopp \& A. BRandT: Nucleotide sequences of cDNA clones for B1 Hordein polypeptides. Carlsberg Res. Commun. 48, 187-199 (1983)

30. Rock, C.O. \& J.E. CRonaN JR.: Reevaluation of the solution structure of acyl carrier protein. J. Biol. Chem. 254, 9778-9785 (1979)

31. Roncari, D.A.K., R.A. Bradshaw \& P.R. VAGELos: Acyl carrier protein. XIX Amino acid sequence of liver fatty acid synthetase peptides containing 4-phosphopantetheine. J. Biol. Chem. 247, 6234-6242 (1972)

32. Rottem, S., O.M. Pered \& S. Razin: Acyl carrier protein in Mycoplasmas. J. Bacteriol. 113, 586-591 (1973)

33. RuCH, F.E. \& P.R. VAGelos: The isolation and general properties of Escherichia coli malonylcoenzyme A acyl carrier protein transacylase. J. Biol. Chem. 248, 8086-8094 (1973)

34. Sabaitas, J.E. \& G.L. Powel.: Acyl carrier protein metabolism and regulation of fatty acid biosynthesis by Lactobacillus plantarum. J. Biol. Chem. 251, 4706-4712 (1976)

35. SCHRECKENBACH, T., H. WOBSER \& F. LYNEN: The palmityl binding sites of fatty acid synthetase from yeast. Eur. J. Biochem. 80, 13-23 (1977)

36. Schultz, H.: The importance of carboxyl groups for the biological activity of acyl carrier protein of Escherichia coli. Biochem. Biophys. Res. Commun. 46, 1446-1453 (1972)

37. Shimakata, T. \& P.K. Stumpf: Fatty acid synthetase of Spinacia oleracea leaves. Plant. Physiol. 69, 1257-1262 (1982)

38. Shimakata, T. \& P.K. StumpF: The purification and function of acetyl coenzyme A: acyl carrier protein transacylase. J. Biol. Chem. 258, 35923598 (1983)

39. Simoni, R.D., R.S. Criddle \& P.K. Stumpf: Fat metabolism in higher plants XXXI. Purification and properties of plant and bacterial acyl carrier proteins. J. Biol. Chem. 242, 573581 (1967) 


\section{P.B. Høs \& I. SVENDSEN: Barley acyl carrier protein}

40. Svendsen, I., B. Martin \& I. Jonassen: Characteristics of hiproly barley III. Amino acid sequences of two lysine-rich proteins. Carlsberg Res. Commun. 45, 79-85, (1980)
41. Vanaman, T., S.J. Wakil \& R.L. Hill: The complete amino acid sequence of the acyl carrier protein of Escherichia coli. J. Biol. Chem. 243, 6420-6431 (1968) 